\title{
Testing the Validity of a Proposed Model for Measuring Customer Satisfaction in Libyan banks Using Confirmatory Factor Analysis
}

\author{
Ali Ramadan Musbah ${ }^{1}$, Nasser Habtoor ${ }^{2}$ \\ ${ }^{1,2}$ Faculty of leadership and Management, Universiti Sains Islam Malaysia, Bandar Baru Nilai, 71800 Nilai, Negeri Sembilan, Malaysia \\ ${ }^{2}$ Aden University, Yemen
}

\begin{abstract}
The current study aimed to test the validity of a proposed model for measuring customer satisfaction in the public commercial banks and their branches in the Libyan context. The proposed model consisted of the dimensions and standards of service quality evaluation based on the (SERVQUAL). In order to achieve this, the researcher used a Confirmatory Factor Analysis (CFA) through the Amos program (Amos 21.0).The study population represented the middle management including directors and heads of departments in the main six commercial banks in Libya and the branches of these banks $(N=402)$. The findings of the study showed that the proposed model was valid and reliable for measuring customer satisfaction in the public commercial banks.
\end{abstract}

Keywords: Material, Reactive, Security, Empathy, Reliability

\section{Introduction}

Customer satisfaction is considered as an important factor that has a positive impact on the survival of any organization and its continuity in the business world. This is more important especially in an environment where competition is intense and where survival is only for those organizations which have a competitive advantage that is inimitable (Belhassen, 2012:31). Within the changing environmental variables, it becomes necessary for successful organizations not only to suffice with achievement of customer satisfaction, but also to measure and determine the degree of such satisfaction and its continuity in addition to the success of the organization in providing the customer's needs and requirements and making such provided services match their needs and desires in a way that leads to building the customer's loyalty to that organization. This is because it is believed that satisfaction results into customer's loyalty and increases his/her frequency of dealings with that given organization, and consequently enabling the organization to achieve the desired profits Customer stratification has been increasingly acquiring much importance in almost all organizations today (Kurdi, 2011: 24). However, the concept of customer satisfaction has raised a great deal of interest and discussion in previous literature because of the difficulties in determining and measuring it especially with the lack of broad consensus among previous researchers and scholars (Rahaman, et al., 2011: 1). In spite of this, the quality of service contributes to determine whether the customer is satisfied or not based on his/her accumulated experience in dealing with organizations that work in the same sector. For example, in commercial banks, customer's satisfaction is represented through his/her assessment or evaluation of the quality of the service after receiving that service (Rahaman, et al., 2011). Therefore, these organizations which are willing to achieve their continued growth in the market need to measure customer satisfaction constantly. Moreover, many pioneers of management believe that the factor of service quality through its dimensions and standards of evaluation according to the (Servqual) is the most important factor by which organizations can measure the levels of customer satisfaction (Darwish, 2009: 7). This is based on the existing strong relationship between them, which confirms that the quality leads to satisfaction (Belbali, 2010: 54).

\section{Research Objectives}

The current study aimed to test the validity of a proposed model for measuring customer satisfaction in the public commercial banks in Libya.

\section{Method}

\subsection{Research Instruments}

In this regard, it is relied upon the questionnaire as a tool to gather the necessary information for this study as one of the most suitable scientific research tools that achieve the survey study objectives and to obtain information and facts associated with a determined reality, for achieving the study, a questionnaire is made for the purposes of processing the studying test the validity of a proposed model for measuring customer satisfaction.

\subsection{Confirmatory Factor Analysis}

The Structural Equation Modeling (AMOS) model-fitting program is used to test the validity constructs are to test the research hypotheses. The overall model fit is assessed by using four indices of the model goodness-of-fit: (1) the chisquare statistics; (2) the comparative fit index (CFI); (3) the minimum value of the discrepancy between the observed data and the hypothesized model divided by degrees of freedom (CMIN/DF) or normed chi-square.(4) In addition( RMSEA) of between $(0.08)$ to $(0.10)$ indicates a mediocre fit and would not employ a model a RMSEA greater than 0.1 $(>0.1)$. 


\section{International Journal of Science and Research (IJSR) \\ ISSN (Online): 2319-7064 \\ Index Copernicus Value (2013): 6.14 | Impact Factor (2014): 5.611}

\subsection{Construct Validity}

The employment of factor loading composite reliability (CR) and average variance extracted (AVE) were proposed by (Hair, Black, Babin, Anderson and Tatham, 2006) to determine the convergent validity if it equals to or greater than $0.5(\geq 0.5)$ and the composite reliability equals to or greater than $0.7(\geq 0.7)$ if were recommended by Hair et al. (2006). In addition (AVE) reading values should be greater than $0.5(\geq 0.5)$.

\section{Results}

\subsection{The Modified Model}

From Figure (1) that shows the results of the CFA for the proposed model for measuring customer satisfaction, it is evident that the model is free of the illogical correlation since it reaches or exceeds the integer (1). This also indicates that there is not any problems in the CFA used for testing the validity of this model that comprises three factors: The first factor including the quality of reliability and the quality of empathy as well as the interactive quality of the service, the second factor including the safety quality and the third factor containing the physical quality of the concrete or actual service. As seen in Figure (1) and Table (1), the indicators of agreement between the model and the data exceeded the T-value, thus, implying that there is disagreement between customer satisfaction and the data of the sample since the value of the Chi-Square was (1154.058) and the degree of freedom was (227), and the level of significance was $(\mathrm{P}=0.000)$. In addition, we can see that the normative Chi-Square (Chi-Square /degrees of freedom) was (5.084) which did not exceed (5) and the value of relative strength index (RSI) was (0.849) being higher than the Tvalue (90). The results also show that the value of the index Rmsea error square was (0.096) being higher than (0.080). Due to this contradiction between the model and the data, it was necessary to modify the customer satisfaction model in this study.

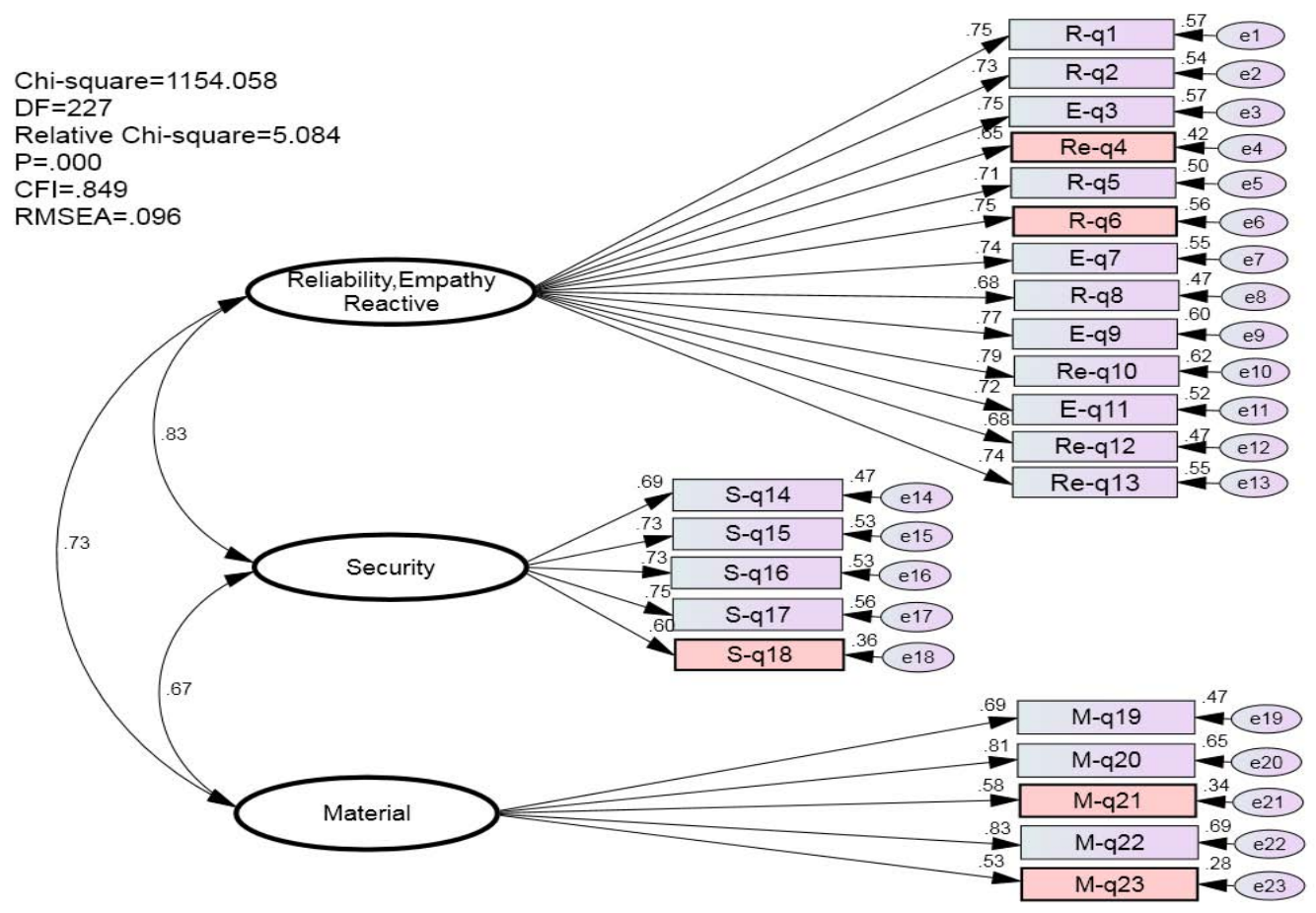

Figure 1:Model customer satisfaction before the amendment

In order to modify this model, we followed two steps: separation of the first factor according the (Servqual) to into three factors: the quality of reliability, the quality of empathy and the interactive quality of the service which were dealt with as three separate factors. The second step was deleting five items (q4, q6, q18, q21 \&q23) where the ratio of saturation or loading these items was the least compared to other items and to what Amos confirmed by analysis of Amos.
Table 1: Index Value of customer satisfaction model before and after modification

\begin{tabular}{|c|c|c|c|}
\hline $\begin{array}{c}\text { Indicators } \\
\text { Consistency }\end{array}$ & $\begin{array}{c}\text { index value } \\
\text { before } \\
\text { modification }\end{array}$ & $\begin{array}{c}\text { index value } \\
\text { after } \\
\text { modification }\end{array}$ & $\begin{array}{c}\text { Function value } \\
\text { on the quality } \\
\text { of conformity }\end{array}$ \\
\hline Cmin & 1154.058 & 419.067 & --- \\
\hline $\mathrm{df}$ & 227 & 125 & --- \\
\hline $\mathrm{P}$ & 0.00 & 0.00 & Non \\
\hline $\mathrm{Cmin} / \mathrm{Df}$ & 5.084 & 3.353 & Less than (5) \\
\hline $\mathrm{CFI}$ & 0.849 & 0.939 & More $(0.90)$ \\
\hline $\mathrm{Rmsea}$ & 0.096 & 0.073 & $\begin{array}{c}\text { Less than } \\
(0.08)\end{array}$ \\
\hline
\end{tabular}

4.2 Confirmatory Factor Analysis of the Customer satisfaction model 


\section{International Journal of Science and Research (IJSR) \\ ISSN (Online): 2319-7064 \\ Index Copernicus Value (2013): 6.14 | Impact Factor (2014): 5.611}

The results of the goodness-of-fit of the final revised of the Customer satisfaction model showed that normed chisquare (CMIN/DF) was (3.353) the CFI was (0.939) and
Rmseawas (0.073). Figure (2) shows the adequacy of the final revised of the Customer satisfaction model.

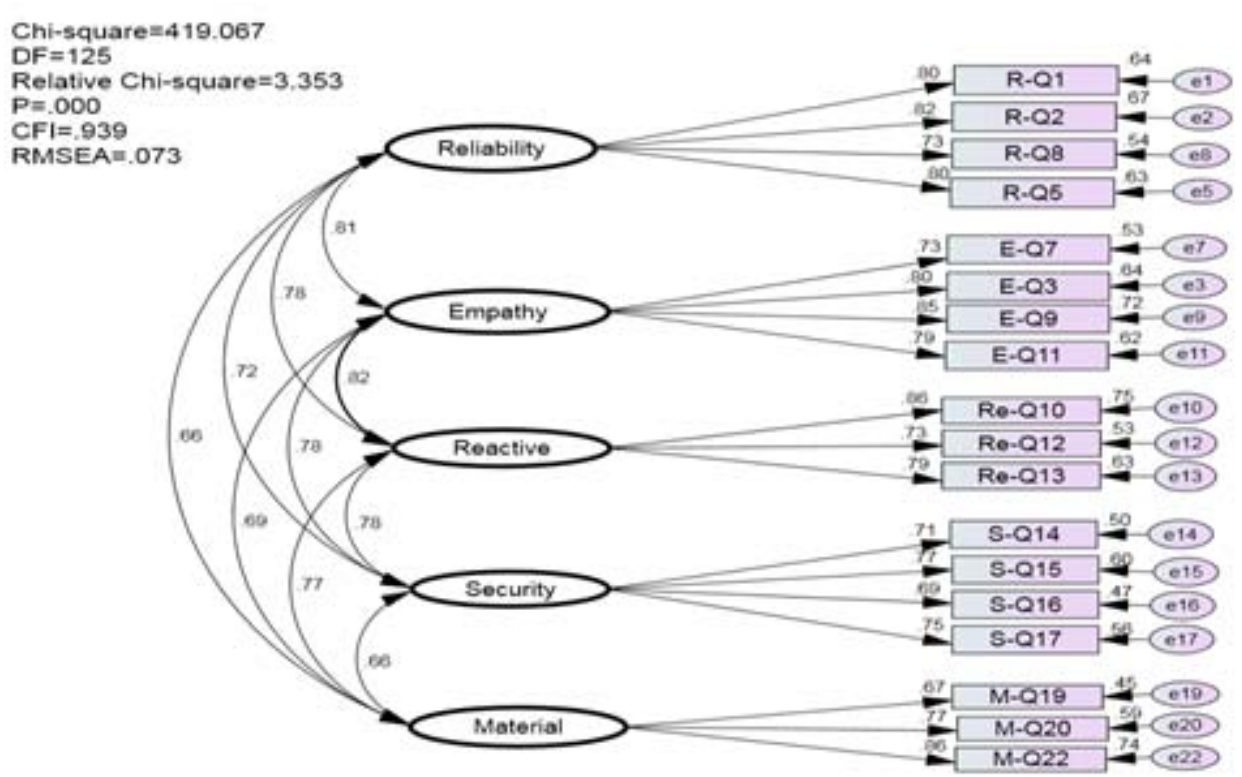

Figure 2: Customer satisfaction model after amendment

\subsection{Construct Validity and Reliability}

In this study, the factor lodging for the parameters ranged from $(0.67$ to 0.86$)$, with all parameters were above $(0.5)$ $(\geq 0.5)$. The reliability ranged from $(0.94$ to 0.94$)$, were greater than $(0.7)(\geq 0.7)$. Furthermore, the AVE readings was $(0.62,0.63,0.64,0.53,0.60)$ where the value was greater than $(0.5)(\geq 0.5)$ Thus, all results fulfilled the AVE, and The reliability discriminant validity of the model. Generally, the measurement model of the Customer satisfaction model was fit and fulfilled the construct as depicted in table (2).

Table 2: Construct Validity and Reliability of Customer satisfaction model

\begin{tabular}{|c|c|c|c|c|c|c|c|c|c|c|}
\hline Item code & variables & Items & Reliability & estimate & S. $E$. & C. $R$. & $P$ & Loading & $R$ & $A V E$ \\
\hline R-q1 & \multirow{4}{*}{ Reliability } & $\begin{array}{l}\text { Suggestions proposed by customers shall be took in } \\
\text { consideration. }\end{array}$ & 0.94 & 1.000 & - & - & - & 0.80 & 0.64 & 0.62 \\
\hline R-q2 & & Service shall be obtained in appropriate time & 0.94 & 0.989 & 0.053 & 18.68 & 0.00 & 0.82 & 0.67 & - \\
\hline R-q8 & & $\begin{array}{l}\text { Problems faced the customers during the service shall } \\
\text { be took in consideration. }\end{array}$ & 0.94 & 0.966 & 0.053 & 18.68 & 0.00 & 0.80 & 0.63 & - \\
\hline R-q5 & & $\begin{array}{l}\text { Required service shall be completed when no } \\
\text { customers. }\end{array}$ & 0.94 & 0.834 & 0.051 & 16.29 & 0.00 & 0.73 & 0.54 & - \\
\hline E-q7 & \multirow{4}{*}{ Empathy } & Customer's requirements shall be continuously studied. & 0.94 & 1.000 & - & - & - & 0.73 & 0.53 & 0.63 \\
\hline E-q3 & & Customers shall participate in social sides. & 0.94 & 1.171 & 0.071 & 16.32 & 0.00 & 0.80 & 0.64 & - \\
\hline E-q9 & & $\begin{array}{l}\text { Short waiting periods for customers shall be } \\
\text { maintained. }\end{array}$ & 0.94 & 1.287 & 0.074 & 17.25 & 0.00 & 0.85 & 0.72 & - \\
\hline E-q11 & & $\begin{array}{l}\text { Customer's requirement shall be acquainted since first } \\
\text { time. }\end{array}$ & 0.94 & 1.131 & 0.070 & 16.05 & 0.00 & 0.79 & 0.62 & - \\
\hline Re-q10 & \multirow{3}{*}{ Reactive } & Quick answer for customer inquiry with smile. & 0.94 & 1.000 & - & - & - & 0.86 & 0.75 & 0.64 \\
\hline Re-q12 & & $\begin{array}{c}\text { Employees shall deal with customers with high morals } \\
\text { and ethics }\end{array}$ & 0.94 & 0.704 & 0.040 & 17.25 & 0.00 & 0.73 & 0.53 & - \\
\hline Re-q13 & & No distinction between customers & 0.94 & 0.927 & 0.047 & 19.60 & 0.00 & 0.79 & 0.63 & - \\
\hline S-q14 & \multirow{4}{*}{ Security } & $\begin{array}{l}\text { Data and information Privacy regarding the customers } \\
\text { shall be respected. }\end{array}$ & 0.94 & 1.000 & - & - & - & 0.71 & 0.50 & 0.53 \\
\hline S-q15 & & $\begin{array}{l}\text { Mistake percentage shall be reduced when required } \\
\text { serviced provided. }\end{array}$ & 0.94 & 1.090 & 0.075 & 14.52 & 0.00 & 0.77 & 0.60 & - \\
\hline S-q16 & & $\begin{array}{l}\text { Confidence shall be maintained when service provided } \\
\text { as required by the customers }\end{array}$ & 0.94 & 0.940 & 0.071 & 13.07 & 0.00 & 0.69 & 0.47 & - \\
\hline S-q17 & & $\begin{array}{c}\text { Behaviors for acquiring confidence to customer in the } \\
\text { bank shall be followed. }\end{array}$ & 0.94 & 1.097 & 0.078 & 14.07 & 0.00 & 0.75 & 0.56 & - \\
\hline M-q19 & \multirow[t]{3}{*}{ Material } & $\begin{array}{l}\text { Recent equipment shall be provided for required } \\
\text { service produced. }\end{array}$ & 0.94 & 1.000 & - & & - & 0.67 & 0.45 & 0.60 \\
\hline M-q20 & & Parking for customers' cars, to be followed to the bank. & 0.94 & 1.529 & 0.112 & 13.64 & 0.00 & 0.77 & 0.59 & - \\
\hline M-q22 & & $\begin{array}{l}\text { Comfortable waiting halls shall be provided for } \\
\text { customers. }\end{array}$ & 0.94 & 1.647 & 0.113 & 14.53 & 0.00 & 0.86 & 0.74 & - \\
\hline
\end{tabular}




\section{Conclusion}

The current study aimed to test the validity of a proposed model for measuring customer satisfaction in the public commercial banks and their branches in Libya. The proposed model included customer satisfaction as a potential variable that is realized through several apparent factors that are the dimensions and standards of service quality evaluation according to the (Servqual). To achieve this research aim, the researcher carried out a CFA by using the Amos program (Amos 21.0). This was test the validity of the model that can be used for measuring the degree and level of customer satisfaction. Based on the results of the analysis and the outputs of the Amos in Figure (1) and Table (1), it is evident that there is disagreement between the model and the data, which emphasizes the need to modify the model. After the model modification as illustrated by Figure (2) and Table (2), there was a match between the model and the sample data based on the goodness of fit indices. Moreover, the average variance extracted (AVE) of all the factors was higher than the standard test factors $(0.50)$. Therefore, it can be concluded that the proposed model in this study has both convergent and discriminate validity, which implies that the model is valid and reliable to be used for measuring and determining the levels of customer satisfaction.

\section{References}

[1] Belhassen, S. (2012).The impact of the quality of services on achieving customer satisfaction. Master Thesis. Merbah Ouargla University, Algeria.

[2] Kurdi, A., A. (2011). Strategic planning for comprehensive quality management of customers' relations. Islam and developmentencyclopedia.

[3] Abdul Kadir, Hazlina, Rahman, Nasim, Masinaei, Reza (2011), Impacts of service quality on customer satisfaction: Study of Online banking and ATM services in Malaysia, International Journal of Trade, Economics and Finance, Vol.2, No.1.

[4] Rahmani, Mohammad Mizenur, Abdullah, Md, Rahmans, Ataur, (2011), Measuring Service Quality using Servqual Model: A Study on PCBs (Private Commercial Banks) in Bangladesh, Business Management Dynamics Vol.1, No.1.

[5] Darwis, M., A. (2009). Theories of leadership and strategies for the acquisition of power. Cairo: the World of Books.

[6] Belbali, A. (2010). The role of internal marketing in achieving the quality of banking services and gaining customer satisfaction. Unpublished Master Thesis, University of Ouargla.

[7] Hair, J. F., Anderson, R. E., Tatham, R. L. \& Black, W. C. (2006). Multivariate Data Analysis (5th ed.), New Jersey, Prentice-Hall. 